prof. dr. sc. Katarina Žager

Ekonomski fakultet, Sveučilište u Zagrebu, Zagreb, Republika Hrvatska kzager@efzg.hr

doc. dr. sc. Nikolina Dečman

Ekonomski fakultet, Sveučilište u Zagrebu, Zagreb, Republika Hrvatska ndecman@efzg.hr

Ana Rep, mag. oec.

Ekonomski fakultet, Sveučilište u Zagrebu, Zagreb, Republika Hrvatska arep@efzg.hr

\title{
UTJECAJ REGULATORNOG OKVIRA ZNANSTVENO- NASTAVNOGA DJELOVANJA VISOKOŠKOLSKIH DJELATNIKA NA KVALITETU RAČUNOVODSTVENE PROFESIJE
}

Primljen: 15. srpnja 2019.

Prihvaćen: 1. listopad 2019.

Pregledni rad

\section{Sažetak}

Znanje je najvrjedniji resurs koji se stječe obrazovanjem i iskustvom. Iako postoje mnogobrojne vrste pa time i definicije znanja može se reći kako ono obuhvaća teorijsko i praktično razumijevanje određene problematike. Znanstveno utemeljeni stavovi čine podlogu za razvoj teorije koja se tada potvrđuje i dodatno razvija u praksi. Stručna znanja primarno se stječu u formalnom sustavu obrazovanja te se nadograđuju kontinuiranim usavršavanjima u poslovnoj praksi. Može se reći kako je obrazovni sustav prva stepenica u razvoju profesionalnih kompetencija stručnjaka iz bilo kojeg područja pa tako i područja računovodstva. Za kvalitetnog stručnjaka iz područja računovodstva potrebna je prije svega kvalitetna podloga u smislu znanja i vještina koje su mu nužne za razumijevanje poslovnih procesa te šireg područja računovodstva i revizije koja se primarno stječu u institucijama visokoškolskog obrazovanja. Kvaliteta rada obrazovne institucije, kao i ishodi učenja koje polaznici stječu na određenim studijima, određena je kvalitetom studijskih programa te osobito kvalitetom nastavnog osoblja. S obzirom na činjenicu kako je jedan od najvažnijih preduvjeta za kvalitetno obrazovanje budućih računovođa upravo kvaliteta visokoškolskih nastavnika važno je sagledati koji su to uvjeti i kriteriji koji potiču izvrsnost u poučavanju te prenošenju stručnih znanja budućim generacijama profesionalnih računovođa. U tom smislu, u radu su istraženi $i$ analizirani kriteriji izvrsnosti nastavnika ekonomske struke $u$ područjima kontinuiranog učenja, poučavanja $i$ sudjelovanja $u$ znanstvenim 
istraživanjima. U postojećem obrazovnom sustavu Republike Hrvatske kvaliteta rada nastavnika visokog obrazovanja mjeri se kriterijima za izbor u znanstvenonastavna zvanja koji, s jedne strane, vrednuju znanstveni rad te, $s$ druge strane, posebno vrednuju nastavnu i stručnu djelatnost nastavnika kao i njihov institucijski doprinos. U cilju saznanja prate li navedeni kriteriji napredovanja nastavnika kriterije izvrsnosti znanstveno-istraživačke te nastavne aktivnosti nastavnika visokog obrazovanja zemalja u okruženju, provedena je komparativna analiza regulatornoga okvira znanstveno-nastavnoga djelovanja nastavnika u području društvenih znanosti - polju ekonomije. Ništa manje važno nije ni saznanje koliko se ulaže u znanost odnosno znanstveno-istraživačke aktivnosti nastavnika budući da se jedino tako mogu osigurati nužni preduvjeti za provedbu istraživačkih projekata koji dovode do novih spoznaja koje se tada prenose i primjenjuju u poslovnoj praksi. Konačno, važno je istaknuti kako se uloga visokoškolskih nastavnika u društvu mijenja te se pored izvrsnosti u poučavanju i prenošenju stručnih znanja budućim generacijama profesionalnih računovođa, sve više očekuje njihov snažan doprinos razvoju i unaprjeđenju cjelokupne društvene zajednice.

Ključne riječi: obrazovanje, regulatorni okvir, znanstveno-nastavna djelatnost, kriteriji napredovanja, računovodstvena profesija

JEL: M41

\section{UVOD}

Računovodstveni informacijski sustav temeljni je izvor informacija za poslovno odlučivanje. Kvaliteta poslovnih odluka zavisi i od kvalitete informacija na temelju kojih se te odluke donose. Kako bi informacije zadovoljavale zakonima i standardima definirane kriterije kvalitete potrebno je raspolagati širokim spektrom stručnih znanja te iste implementirati u samom procesu generiranja informacija. U tom kontekstu posebno važnu ulogu ima računovodstvena profesija. Računovodstvena profesija jedna je od temeljnih profesija bez koje ne bi bilo kvalitetnih i pouzdanih informacija za poslovno odlučivanje. Stoga je vrlo važno da ona bude educirana i organizirana na kvalitetan način.

U većini zemalja ne postoji zakonska obveza certificiranja i licenciranja računovodstvenih zvanja. $U$ takvim okolnostima prilikom razmatranja kvalitete rada računovođa posebno je važno uzeti u obzir njihovo obrazovanje i izlazne kompetencije koje stječu formalnim obrazovanjem. Računovodstvena profesija generira se iz postojećeg sustava srednjoškolskog i visokoškolskog obrazovanja. Formalno obrazovanje se ne događa samo po sebi. Ono je organiziran i kontroliran sustav. Karakterizira ga, između ostalog, sadržaj i kvaliteta računovodstvenih programa, ali i kvaliteta nastavnika koji prenose stručna znanja na buduće računovođe. Prijenos stručnih znanja te praćenje i usvajanje novih spoznaja 
temeljni je zadatak svakog edukatora, a posebno nastavnika u sustavu visokoškolskog obrazovanja u okviru kojeg se generira i najveći i najznačajniji broj računovodstvenih djelatnika. Kada se u obzir uzme i činjenica da su upravo računovođe $s$ završenim visokoškolskim obrazovanjem često $i$ na najvišim rukovodećim mjestima koja podrazumijevaju i najvišu razinu odgovornosti, kako za pripremu tako i za upotrebu informacija, tada nije nevažno što su i od koga učili odnosno kako su stjecali znanja i vještine koje u svom svakodnevnom poslovanju koriste.

Sustav visokoškolskog obrazovanja je organiziran, reguliran i kontroliran sustav koji osim izvođenja studijskih programa podrazumijeva i brojna znanstvena istraživanja čiji rezultati unaprjeđuju postojeći sustav obrazovanja i na taj način dodatno doprinose kvaliteti izlaznih kompetencija osoba koje izlaze na tržište rada. Nastavničke kompetencije najznačajniji su preduvjet osiguranja kvalitete visokoškolskog obrazovanja, općenito za sve profesije, a posebice računovodstvenu. Sve više se govori o standardima kvalitete rada i kriterijima izvrsnosti kojima se potiče kontinuirano učenje i stjecanje novih znanja koja treba dalje prenositi na buduće generacije poslovnih ljudi. Zato znanstvenu i nastavnu komponentu rada nastavnika treba promatrati zajedno kao međusobno povezanu cjelinu koja osigurava sinergijski učinak na kvalitetu rada, a posebno na prijenos znanja na nove generacije koje će to znanje primjenjivati u poslovnoj praksi. Zbog izuzetnog značaja za sadašnjost, ali i za budućnost, taj proces nije prepušten stihiji već je reguliran brojnim zakonima. Regulatorni okvir neizostavni je element koji treba uzeti u obzir prilikom utvrđivanja ishoda učenja i kompetencija koje računovođe posjeduju posebno u uvjetima kada ne postoji zakonska obveza provjere znanja i stručnosti kroz naknadno certificiranje i licenciranje računovodstvenih zvanja. Za očekivati je da zahtjevniji programi obrazovanja i visoko kvalitetan nastavni kadar generiraju i kvalitetnije računovođe koji sa svojim stručnim kompetencijama mogu kvalitetnije odgovoriti na izazove koji se pred današnje računovođe postavljaju. Stoga su u nastavku rada analizirani visokoškolski nastavni programi za izobrazbu računovođa kao i kriteriji ocjene kvalitete rada nastavnika koji te računovođe obrazuju.

\section{VISOKOŠKOLSKO OBRAZOVANJE KAO TEMELJ ZA STJECANJE PROFESIONALNIH KOMPETENCIJA RAČUNOVODSTVENIH DJELATNIKA}

\subsection{Osnovna obilježja regulatornog okvira znanstvene djelatnosti i visokog obrazovanja u Republici Hrvatskoj}

„Znanost, u širem smislu predstavlja skup svih sustavno metodski stečenih i uobličenih znanja te obuhvaća djelatnost kojom se stječu takva znanja. U užem smislu, znanost se definira kao skup znanja dobivenih nekom od 
znanstvenih metoda, te racionalna djelatnost predviđanja i objašnjenja pojava $u$ okolini (znanstveno znanje) koja se ostvaruje svođenjem pojedinih pojava pod univerzalne zakone“ (Leksikografski zavod Miroslav Krleža). „Glavna je svrha znanstvene politike Republike Hrvatske stvoriti znanstveni i tehnologijski napredak koji će biti jedan od ključnih čimbenika društvenoga i gospodarskog razvoja države. Kvalitetna se znanost temelji na kvalitetnom i djelotvornom obrazovanju za znanost, visokim standardima izvrsnosti i povećanom izdvajanju iz javnog i privatnog sektora“ (Agencija za znanost i visoko obrazovanje, 2018, 28). Temeljni pravni akt koji uređuje sustav znanstvene djelatnosti i visokog obrazovanja u Republici Hrvatskoj je Zakon o znanstvenoj djelatnosti i visokom obrazovanju (NN 123/03, 105/04, 174/04, 2/07 - Odluka Ustavnog suda Republike Hrvatske, 46/07, 45/09, 63/11, 94/13, i 139/13). Sukladno navedenom Zakonu zadaća razvitka i osiguranja kvalitete cjelokupne znanstvene djelatnosti i sustava znanosti, visokog obrazovanja i tehnološkog razvoja u Republici Hrvatskoj povjerena je najvišem stručnom tijelu - Nacionalnom vijeću za znanost, visoko obrazovanje i tehnološki razvoj. Pored Nacionalnog vijeća, razvoju i kvaliteti znanstvene djelatnosti i sustava znanosti u Republici Hrvatskoj svakako pridonose Ministarstvo znanosti i obrazovanja, Hrvatska zaklada za znanost te Agencija za znanost i visoko obrazovanje.

Nositelji znanstvene djelatnosti u Republici Hrvatskoj su javni znanstveni instituti, visoka učilišta te ostale pravne osobe izvan sustava visokog obrazovanja i javnih znanstvenih instituta koje su registrirale znanstvenu djelatnost. "U Hrvatskoj su znanstvenu djelatnost registrirale 182 pravne osobe, čime su se upisale u Upisnik znanstvenih organizacija i stekle pravo na javno financiranje i to:

- 25 javnih znanstvenih instituta,

- 87 visokih učilišta (VU), i to: 10 sveučilišta (8 javnih i 2 privatna sveučilišta), 72 sastavnice javnih sveučilišta (fakulteti, akademije i odjeli), 4 visoke škole ( 2 javne i 2 privatne ) te 4 javna veleučilišta,

- 70 pravnih osoba izvan sustava visokog obrazovanja i javnih znanstvenih instituta koje su registrirale znanstvenu djelatnost, i to: 3 ustanove od posebnog značaja (Nacionalna sveučilišna knjižnica, HAZU, Leksikografski zavod „Miroslav Krleža"), bolnice i zdravstvene ustanove $s$ istraživačkim jedinicama, državni instituti i zavodi (4), arhivi, muzeji i dr.” (Agencija za znanost i visoko obrazovanje, 2019).

Neosporna je činjenica da bez kvalitetnog obrazovanja nema ni kvalitetnih stručnjaka, a time niti gospodarskog napretka i prosperiteta jedne države. Budući da su obrazovanje i znanost međusobno povezani posebno je važno ulagati u znanost koja je usmjerena razvoju novih znanja koja se prenose budućim generacijama te omogućuju primjenu istih s ciljem društvenog i gospodarskog razvoja države. Danas smo svjedoci snažnih globalizacijskih procesa na međunarodnoj razini. U nacionalnim okvirima dogodile su se značajne „društvene, ekonomske, kulturološke i demografske promjene koje zahtijevaju dugoročno 
promišljanje o mjestu obrazovanja i znanosti u društvu, a napose u stvaranju inovativnog društva i gospodarstva, prilagodljivog budućim izazovima koje je danas teško ili nemoguće predvidjeti“ (Ministarstvo znanosti, obrazovanja i sporta, 2014, 19). Sve navedeno zahtijevalo je izradu nacionalne Strategije obrazovanja, znanosti i tehnologije. U provedbi mjera za postizanje ciljeva Strategije posebnu važna uloga pripada visokim učilištima te znanstvenim institutima. Kao najznačajniji ciljevi Strategije za razvoj znanosti posebno se ističu „,brže pokretanje promjena u sustavu visokog obrazovanja i znanosti, postojanje međunarodno kompetitivnih javnih sveučilišta $\mathrm{i}$ javnih znanstvenih instituta $\mathrm{u}$ hrvatskome visokoobrazovnom i istraživačkom prostoru koji stvaraju novu znanstvenu, društvenu, kulturnu i gospodarsku vrijednost kao i stvaranje okruženja koje omogućuje i potiče interakciju istraživačke zajednice s inovativnim gospodarstvom i društvenim djelatnostima. Kao posebno važan cilj ističe se i rast ulaganja u istraživanje i razvoj unapređenjem sustava javnog financiranja te poticanjem ulaganja poslovnog i društvenog sektora $\mathrm{u}$ istraživanje i razvoj“ (Ministarstvo znanosti, obrazovanja i sporta, 2014, 213-250). Prema posljednjim podacima „u 2017. u Republici Hrvatskoj utrošeno je 2,6 milijardi kuna sredstava državnog proračuna za aktivnost istraživanja i razvoja. Pri tome, prema društvenoekonomskim ciljevima, najviše sredstava državnog proračuna za istraživanje i razvoj $(49,4 \%)$ bilo je utrošeno za cilj Opće unapređenje znanja: istraživanje i razvoj financiran iz fondova visokih učilišta (Državni zavod za statistiku, 2018). U okviru visokih učilišta značajna uloga u znanstveno-istraživačkom smislu pripada sveučilištima. Budući da je kompetitivnost sveprisutna u području visokog obrazovanja ne iznenađuje podatak kako se mijenja i sam sustav financiranja sveučilišta. „U 2018. godini pristupilo se „strukturnoj promjeni financiranja koja za krajnji cilj ima uspostaviti cjelovito financiranje visokog obrazovanja i znanosti temeljeno na postizanju rezultata i strateških ciljeva na načelima transparentnosti, učinkovitosti, osiguravanju kvalitete i socijalne dimenzije u visokom obrazovanju“ (Ministarstvo znanosti i obrazovanja, 2019).

\subsection{Organizacija visokoškolskog obrazovanja u Republici Hrvatskoj}

Znanje je najvrjedniji resurs koji se stječe obrazovanjem i iskustvom. Iako postoje mnogobrojne vrste pa time i definicije znanja može se reći kako ono obuhvaća teorijsko i praktično razumijevanje određene problematike. Znanstveno utemeljeni stavovi čine podlogu za razvoj teorije koja se tada potvrđuje i dodatno razvija u praksi. Stručna znanja primarno se stječu u formalnom sustavu obrazovanja te se nadograđuju kontinuiranim usavršavanjima u poslovnoj praksi. Može se reći kako je obrazovni sustav prva stepenica u razvoju profesionalnih kompetencija stručnjaka iz bilo kojeg područja pa tako i područja računovodstva. Za kvalitetnog stručnjaka iz područja računovodstva potrebna je prije svega kvalitetna podloga u smislu znanja i vještina koje su mu nužne za razumijevanje poslovnih procesa te šireg područja računovodstva i revizije koja se primarno stječu u institucijama visokoškolskog obrazovanja. 
U cilju razumijevanja sustava visokog obrazovanja posebno je važno poznavati oblike organizacije visokih učilišta te razine studijskih programa koji se izvode u obliku sveučilišnih i stručnih studija (tablica 1). Visoka učilišta u Hrvatskoj čine sveučilišta (sa svojim sastavnicama - fakultetima i umjetničkim akademijama), veleučilišta i visoke škole. Sveučilišta su ustanove koje primarno organiziraju i izvode sveučilišne studijske programe, a mogu izvoditi stručne studijske programe dok veleučilišta i visoke škole primarno izvode stručne studijske programe. Trenutno u Hrvatskoj postoji 119 visokih učilišta sa statusom ustanove, od čega 8 javnih sveučilišta, 2 privatna sveučilišta, 68 fakulteta i umjetničkih akademija te 1 sveučilišni centar na javnim sveučilištima, 4 privatna veleučilišta, 11 javnih veleučilišta, 22 privatne visoke škole i 3 javne visoke škole (Agencija za znanost i visoko obrazovanje, 2019).

Tablica 1. Vrste i razine studijskih programa u Republici Hrvatskoj

\begin{tabular}{|c|c|}
\hline \multirow{3}{*}{$\begin{array}{c}\text { SVEUČILIŠNI } \\
\text { STUDIJ } \\
\text { osposobljava studente } \\
\text { za obavljanje poslova u } \\
\text { znanosti, umjetnosti i } \\
\text { visokom obrazovanju, u } \\
\text { poslovnom svijetu, } \\
\text { javnom sektoru i } \\
\text { društvu općenito te ih } \\
\text { osposobljava za razvoj i } \\
\text { primjenu znanstvenih, } \\
\text { umjetničkih i stručnih } \\
\text { dostignuća }\end{array}$} & $\begin{array}{l}\text { PREDDIPLOMSKI SVEUČILIŠNI STUDIJ } \\
\text { - traje od tri do četiri godine } \\
\text { - završetkom se stječe od } 180 \text { do } 240 \text { ECTS bodova } \\
\text { - završetkom se stječe akademski naziv } \\
\text { prvostupnik/prvostupnica (baccalaureus odnosno baccalaurea) } \\
\text { uz naznaku struke }\end{array}$ \\
\hline & $\begin{array}{l}\text { DIPLOMSKI SVEUČILIŠNI STUDIJ } \\
\text { - traje od jedne do dvije godine } \\
\text { - završetkom se stječe od } 60 \text { do } 120 \text { ECTS bodova } \\
\text { - završetkom se stječu akademski nazivi: } \\
\text { 1. za sveučilišne medicinske programe doktor (dr.) struke } \\
\text { 2. za ostale sveučilišne programe magistar, odnosno magistra } \\
\text { (mag.) struke }\end{array}$ \\
\hline & $\begin{array}{l}\text { POSLIJEDIPLOMSKI SVEUČILIŠNI STUDIJ } \\
\text { A. POSLIJEDIPLOMSKI SPECIJALISTIČKI STUDIJ } \\
\text { - traje od jedne do dvije godine } \\
\text { - završetkom se stječe od } 60 \text { do } 120 \text { ECTS bodova } \\
\text { - završetkom se stječe akademski naziv specijalist područja } \\
\text { (univ. spec.) } \\
\text { B. POSLIJEDIPLOMSKI SVEUČILIŠNI STUDIJ } \\
\text { (DOKTORSKI STUDIJ) } \\
\text { - može se upisati nakon završenoga diplomskoga sveučilišnog } \\
\text { studija } \\
\text { - traje najmanje tri godine } \\
\text { - završetkom se stječe akademski stupanj doktor znanosti (dr. } \\
\text { sc.) odnosno doktor umjetnosti (dr. art.) }\end{array}$ \\
\hline \multirow[t]{2}{*}{$\begin{array}{l}\text { STRUČNI STUDIJ } \\
\text { osposobljava studente } \\
\text { za neposredno } \\
\text { uključivanje u radni } \\
\text { proces }\end{array}$} & $\begin{array}{l}\text { KRATKI STRUČNI STUDIJ } \\
\text { - traje od dvije do dvije i pol godine } \\
\text { - završetkom se stječe od } 120 \text { do } 150 \text { ECTS bodova } \\
\text { - stručni naziv stručni pristupnik / stručna pristupnica uz } \\
\text { naznaku struke }\end{array}$ \\
\hline & PREDDIPLOMSKI STRUČNI STUDIJ \\
\hline
\end{tabular}




\begin{tabular}{|l|l|}
\hline & $\begin{array}{l}\text { - traje tri godine (iznimno četiri godine) } \\
\text { - završetkom se stječe od } 180 \text { do } 240 \text { ECTS bodova } \\
\text { - stručni naziv stručni prvostupnik / stručna prvostupnica } \\
\text { (baccalaureus/baccalaurea) uz naznaku struke }\end{array}$ \\
\cline { 2 - 3 } SPECIJALISTIČKI DIPLOMSKI STRUČNI STUDIJ \\
- traje jednu ili dvije godine \\
- završetkom se stječe od 60 do 120 ECTS bodova \\
- stručni naziv stručni specijalist / stručna specijalistica \\
određene struke
\end{tabular}

Izvor: Obrada autora prema Agencija za znanost i visoko obrazovanje, 2018

\subsection{Analiza usklađenosti zahtijevanih profesionalnih kompetencija računovođa sa ishodima učenja ostvarenim pohađanjem studijskih programa namijenjenih obrazovanju računovođa u Republici Hrvatskoj}

Međunarodna federacija računovođa (International Federation of Accountants IFAC) kao najpoznatija i najznačajnija globalna organizacija koja promovira kvalitetu rada računovodstvene profesije prepoznaje važnost edukacije, a njen doprinos razvoju računovodstvene profesije posebno se očituje kroz izradu Međunarodnih standarda edukacije (International Education Standards - MSE) za profesionalne računovođe. Navedeni Standardi su razvijani s primarnim ciljem promoviranja općeprihvaćenih standarda kvalitete u obrazovanju i razvoju profesionalnih računovođa te su namijenjeni organizacijama članicama IFAC-a odnosno tijelima koji direktno ili indirektno utječu na sustav obrazovanja i razvoj profesije računovođa na nacionalnoj razini (detaljnije o Međunarodnim standardima edukacije vidjeti: Žager, Sever Mališ, Dečman, 2016, 393-400). Standardima su, između ostalog, definirane tehničke kompetencije koje bi potencijalni profesionalni računovođe trebali razviti te konačno i demonstrirati na kraju programa inicijalnog profesionalnog obrazovanja kako bi mogli obnašati ulogu ovlaštenog računovođe. Budući da trenutno u Republici Hrvatskoj ne postoji zakonska obveza certificiranja i licenciranja računovodstvenih zvanja može se reći da je u takvim okolnostima kvaliteta rada računovodstvenih djelatnika primarno determinirana stečenim profesionalnim kompetencijama putem formalnog obrazovanja.

Neosporno je da zahtjevniji programi obrazovanja podrazumijevaju stjecanje boljih stručnih kompetencija te veću sposobnost razvoja i primjene znanstvenih dostignuća u praksi. Stoga su navedene zadaće povjerene sveučilištima odnosno fakultetima koji, zavisno o vrstu financiranja, mogu biti javni ili privatni. Jedan od važnih čimbenika kvalitete rada obrazovne institucije svakako su nastavni programi te ishodi učenja koji se stječu pohađanjem studija. Iz navedenih razloga u nastavku rada analizirani su visokoškolski nastavni programi za izobrazbu budućih računovodstvenih djelatnika koji se izvode u okviru najznačajnijih visokih učilišta iz područja društvenih znanosti polja ekonomije kojima je osnivač Republika Hrvatska i koji se dominantno financiraju iz državnog proračuna. U analizi su 
obuhvaćena četiri ekonomska fakulteta koja djeluju u okviru najvećih javnih sveučilišta Republike Hrvatske. (Detaljnije o studijskim programima namijenjenih obrazovanju računovođa u Republici Hrvatskoj vidjeti Žager, Dečman, Rep, 2015, str. 8-17). Analiza usklađenosti zahtijevanih profesionalnih kompetencija računovođa sa specijalističkim znanjima koja se stječu izučavanjem kolegija $u$ okviru studijskih programa namijenjenih obrazovanju računovođa $u$ Republici Hrvatskoj prikazana je u tablici 2. $\mathrm{Na}$ temelju usporedbe zahtijevanih profesionalnih tehničkih kompetencija računovođa određenih od strane IFAC-a i računovodstvenih kolegija odnosno znanja koja se stječu na našim fakultetima može se zaključiti da naš sustav obrazovanja računovođa zadovoljava potrebne tehničke kompetencije definirane Međunarodnim standardima edukacije računovođa. Analiza pokazuje i kako Ekonomski fakultet u Zagrebu te Ekonomski fakultet u Splitu nude najveći broj kolegija računovodstvenoga sadržaja što svakako daje dodanu vrijednost svim računovođama koji nose diplomu navedenih fakulteta.

Tablica 2. Usporedba zahtijevanih profesionalnih kompetencija računovođa prema Međunarodnim standardima edukacije i kolegija koji se izvode na ekonomskim fakultetima u Republici Hrvatskoj

\begin{tabular}{|c|c|}
\hline $\begin{array}{c}\text { Organizacija/nositelj studijskog } \\
\text { programa }\end{array}$ & $\begin{array}{c}\text { Tehničke kompetencije/kolegiji koji se izvode u } \\
\text { okviru preddiplomskog i diplomskog sveučilišnog } \\
\text { studija }\end{array}$ \\
\hline $\begin{array}{c}\text { IFAC - Međunarodni standardi } \\
\text { edukacije }\end{array}$ & $\begin{array}{l}\text { - Financijsko računovodstvo i izvještavanje } \\
\text { - Upravljačko računovodstvo } \\
\text { - Financije i financijski menadžment } \\
\text { - Oporezivanje } \\
\text { - Revizija } \\
\text { - Korporativno upravljanje, upravljanje rizicima i } \\
\text { interne kontrole } \\
\text { - Zakoni i propisi } \\
\text { - Informacijske tehnologije } \\
\text { - Poslovno i organizacijsko okruženje } \\
\text { - Ekonomija } \\
\text { - Poslovna strategija i menadžment }\end{array}$ \\
\hline $\begin{array}{l}\text { Ekonomski fakultet - Zagrebu } \\
\text { Integrirani preddiplomski i } \\
\text { diplomski sveučilišni studij } \\
(5+0)\end{array}$ & $\begin{array}{l}\text { - Računovodstvo I } \\
\text { - Računovodstvo II } \\
\text { - Financijsko računovodstvo } \\
\text { - Upravljačko računovodstvo } \\
\text { - Računovodstvo troškova } \\
\text { - Računovodstvo poreza } \\
\text { - Računovodstveni informacijski sustavi } \\
\text { - Računovodstvo malih i srednjih poduzeća } \\
\text { - Računovodstvo neprofitnih organizacija } \\
\text { - Računovodstvo financijskih institucija } \\
\text { - Međunarodno računovodstvo } \\
\text { - Revizija } \\
\text { - Interna revizija }\end{array}$ \\
\hline
\end{tabular}




\begin{tabular}{|c|c|}
\hline & $\begin{array}{l}\text { - Državna revizija } \\
\text { - Analiza financijskih izvještaja }\end{array}$ \\
\hline $\begin{array}{c}\text { Ekonomski fakultet -Split } \\
\text { Preddiplomski sveučilišni studij i } \\
\text { diplomski sveučilišni studij } \\
(3+2)\end{array}$ & $\begin{array}{l}\text { - Računovodstvo } \\
\text { - Managersko računovodstvo I } \\
\text { - Financijsko računovodstvo I } \\
\text { - Osnove revizije } \\
\text { - Računovodstvo troškova I } \\
\text { - Računovodstvo financijskih institucija } \\
\text { - Računovodstvo obrtnika } \\
\text { - Računovodstvo neprofitnih organizacija } \\
\text {-- }- \text { - } \\
\text { - Financijsko računovodstvo II } \\
\text { - Revizija } \\
\text { - Računovodstvo troškova II } \\
\text { - Interna kontrola i revizija } \\
\text { - Managersko računovodstvo II } \\
\text { - Računovodstveni standardi } \\
\text { - Računovodstvo novčanih tijekova }\end{array}$ \\
\hline $\begin{array}{l}\text { Ekonomski fakultet - Rijeka } \\
\text { Preddiplomski sveučilišni studij i } \\
\text { diplomski sveučilišni studij } \\
(3+2)\end{array}$ & $\begin{array}{l}\text { - Računovodstvo } \\
\text { - Računovodstvo malih i srednjih poduzeća } \\
\text { - Financijsko računovodstvo } \\
\text { - Računovodstvo financijskih institucija } \\
\text { - Financijsko računovodstvo } \\
\text { - Računovodstvo troškova } \\
\text { - Međunarodno računovodstvo } \\
\text { - Revizija } \\
\text { - Menadžersko računovodstvo } \\
\text { - Računovodstvo proračuna i neprofitnih } \\
\text { organizacija }\end{array}$ \\
\hline $\begin{array}{c}\text { Ekonomski fakultet - Osijek } \\
\text { Preddiplomski sveučilišni studij i } \\
\text { diplomski sveučilišni studij } \\
(3+2)\end{array}$ & $\begin{array}{l}\text { - Računovodstvo } \\
\text { - Financijsko računovodstvo } \\
\text { - Analiza financijskih izvještaja } \\
\text { - Organizacija IS u financijama i računovodstvu } \\
\text { - Revizija } \\
\text { - Revizija financijskih institucija } \\
\text { - Bilanciranje } \\
\text { - Računovodstvo banaka i osiguravajućih društava } \\
\text { - Računovodstvo proračuna i neprofitnih } \\
\text { organizacija }\end{array}$ \\
\hline
\end{tabular}

Izvor: Obrada autora prema IAESB, 2015, 34-38 i službenih Internet stranica najvećih ekonomskih fakulteta u Republici Hrvatskoj 


\section{ZNAČAJ KVALITETE RADA EDUKATORA U OSIGURANJU KVALITETE RADA RAČUNOVODSTVENE PROFESIJE}

S obzirom na činjenicu kako je jedan od najvažnijih preduvjeta za kvalitetno obrazovanje budućih računovođa upravo kvaliteta visokoškolskih nastavnika, važno je sagledati koji su to uvjeti i kriteriji koji potiču izvrsnost u poučavanju te prenošenju stručnih znanja budućim generacijama profesionalnih računovođa. U tom smislu, u radu su istraženi i analizirani kriteriji izvrsnosti nastavnika ekonomske struke u područjima kontinuiranog učenja, poučavanja i sudjelovanja u znanstvenim istraživanjima.

\subsection{Analiza kriterija napredovanja znanstveno-nastavnih djelatnika na visokim učilištima u Republici Hrvatskoj}

U postojećem obrazovnom sustavu Republike Hrvatske kvaliteta rada nastavnika visokog obrazovanja mjeri se kriterijima za izbor u znanstveno-nastavna zvanja koji, s jedne strane, vrednuju znanstveni rad te, s druge strane, posebno vrednuju nastavnu i stručnu djelatnost nastavnika kao i njihov institucijski doprinos. Prije nego će se navesti kriteriji izbora u znanstveno-nastavna zvanja nastavnika potrebno je prikazati klasifikaciju znanstveno-nastavnih zvanja i radnih mjesta na visokim učilištima u RH (Tablica 3).

Tablica 3. Klasifikacija znanstveno-nastavnih zvanja i radnih mjesta na visokim učilištima u RH

\begin{tabular}{|c|c|}
\hline \multicolumn{2}{|c|}{ RADNA MJESTA NA SVEUČILIŠTIMA } \\
\hline Znanstveno-nastavna zvanja i radna mjesta & $\begin{array}{ll}\text { - } & \text { docent } \\
\text { - } & \text { izvanredni profesor } \\
\text { - } & \text { redoviti profesor } \\
\end{array}$ \\
\hline $\begin{array}{l}\text { Suradnička zvanja } i \\
\text { radna mjesta }\end{array}$ & $\begin{array}{ll}\text { - } & \text { asistent } \\
\text { - } & \text { poslijedoktorand } \\
\end{array}$ \\
\hline $\begin{array}{l}\text { Stručna zvanja i } \\
\text { radna mjesta }\end{array}$ & $\begin{array}{ll}\text { - } & \text { stručni suradnik } \\
\text { - } & \text { viši stručni suradnik } \\
\text { - } & \text { stručni savjetnik }\end{array}$ \\
\hline \multicolumn{2}{|c|}{$\begin{array}{l}\text { RADNA MJESTA NA VELEUČILIŠTIMA i } \\
\text { VISOKIM POSLOVNIM ŠKOLAMA }\end{array}$} \\
\hline $\begin{array}{l}\text { Nastavna zvanja i } \\
\quad \text { radna mjesta }\end{array}$ & $\begin{array}{ll}\text { - } & \text { predavač } \\
\text { - } & \text { viši predavač } \\
\text { - } & \text { profesor visoke škole } \\
\text { - } & \text { profesor visoke škole u trajnom zvanju } \\
\text { - } & \text { lektor } \\
\text { - } & \text { viši lektor } \\
\text { - } & \text { umjetnički suradnik umjetnički suradnik } \\
\text { - } & \text { umjetnički savjetnik }\end{array}$ \\
\hline
\end{tabular}

Izvor: Obrada autora prema Agencija za znanost i visoko obrazovanje, 2018 
Radna mjesta ovise o zvanju u koje je nastavnik izabran. U pravilu, na prvo radno mjesto na Sveučilištu, mjesto asistenta, izabiru se najuspješniji studenti koja sklapaju ugovor o radu na vrijeme od šest godina te se obvezuju pohađati i završiti poslijediplomski sveučilišni doktorski studij kao temeljnu pretpostavku daljnjeg napredovanja. Asistenti i poslijedoktorandi pomažu u provođenju nastavnog procesa, u pravilu izvođenjem vježbi i seminara, dok predavanja održavaju nastavnici koji su minimalno izabrani u znanstveno-nastavno zvanje docenta ili više. Sukladno Zakonu o znanstvenoj djelatnosti i visokom obrazovanju, u znanstveno-nastavno zvanje može biti izabrana osoba koja je upisana u Upisnik znanstvenika pri čemu se zahtjeva odgovarajuće znanstveno zvanje stečeno u odgovarajućem polju i ostale uvjete u pogledu obrazovnoga, nastavnog i stručnog rada koje propisuje Rektorski zbor. Razlikuju se četiri znanstvena zvanja; znanstveni suradnik, viši znanstveni suradnik, znanstveni savjetnik i znanstveni savjetnik u trajnom zvanju. Osnovni uvjet za stjecanje znanstvenog zvanja je akademski stupanj doktora znanosti te određeni, Pravilnikom definirani, broj i vrsta broj relevantnih znanstvenih radova. Jednom stečeno znanstveno zvanje je trajno te ne ovisi o radnom mjestu, a prestaje prelaskom u više znanstveno zvanje ili njegovim oduzimanjem. U ožujku 2017. godine Nacionalno vijeće za znanost, visoko obrazovanje i tehnološki razvoj donijelo je Pravilnik o uvjetima za izbor u znanstvena zvanja (NN 28/17) kojim su značajno unaprijeđeni uvjeti za izbor u znanstvena zvanja u odnosu na Pravilnik o uvjetima za izbor u znanstvena zvanja (NN 84/05, 100/06, 138/06, 120/07, 71/10, 116/10 i 38/11). U tablici 4. dan je komparativni prikaz aktualnih i ranije važećih uvjeta za izbor u znanstvena zvanja u znanstvenom području društvenih znanosti (grana računovodstvo pripada društvenim znanostima i to polju ekonomije). U odnosu na stari Pravilnik uvedene su značajne novine. Prije svega, uvedena je nova kategorija znanstvenog zvanja, a to je znanstveni savjetnik u trajnom zvanju. Nadalje, uvedene su tri kategorije radova a1, a2 i a3 pri čemu su radovi a1 skupine isključivo oni koji su objavljeni u visoko kvalitetnim znanstvenim časopisima ili zbornicima radova s međunarodnih znanstvenih skupova indeksiranih u bazama podataka WoSCC ili Scopus. Također je za napredovanje potrebno objaviti više znanstvenih radova za određeno zvanje budući da svi radovi više nemaju koeficijent 1 , već se broj bodova pridružuje sukladno vrsti i kvaliteti rada odnosno kvaliteti baze u kojoj se rad nalazi $(0,5$, $0,75,1)$. Dodatno se potiče izvrsnost kroz objavljivanje radova u visoko rangiranim publikacijama (primjerice za radove objavljene u bazama WoSCC i Scopus koji se nalaze u prvom i drugom kvartilu pridružuju se dva boda). Također potrebno je istaknuti da se kroz nove uvjete napredovanja definiraju i zahtjevi kontinuiranog rada i usavršavanja. Dok je starim pravilnikom za izbor u određeno zvanje bio definiran ukupan broj radova bez obzira na vrijeme kad su objavljeni novi pravilnik primarno je fokusiran na analizu i ocjenu tzv. delte odnosno radova i uvjeta ostvarenih nakon izbora u prethodno znanstveno zvanje što dodatno motivira na kontinuirani rad na istraživanjima i stjecanje novih spoznaja. 
Tablica 4. Analiza kriterija za izbor u znanstvena zvanja u znanstvenom području društvenih znanosti

\begin{tabular}{|c|c|c|c|c|c|}
\hline \multicolumn{6}{|c|}{$\begin{array}{c}\text { KRITERIJI ZA IZBOR U ZNANSTVENA ZVANJA SUKLADNO } \\
\text { AKTUALNOM PRAVILNIKU O UVJETIMA ZA IZBOR U ZNANSTVENA } \\
\text { ZVANJA (NN 28/17) }\end{array}$} \\
\hline \multirow{2}{*}{$\begin{array}{l}\text { ZNANSTVENA } \\
\text { ZVANJA }\end{array}$} & \multicolumn{5}{|c|}{ BROJ POTREBNIH BODOVA po vrsti radova } \\
\hline & a1 & a2 & a & & Ukupno \\
\hline $\begin{array}{ll}\text { - } & \text { znanstveni } \\
\text { suradnik }\end{array}$ & 3 & 2 & 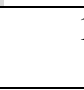 & & 6 \\
\hline $\begin{array}{ll}\text { - } & \text { viši znanstveni } \\
& \text { suradnik }\end{array}$ & 4 & 2 & 2 & & 8 \\
\hline $\begin{array}{ll}\text { znanstveni } \\
\text { savjetnik }\end{array}$ & 5 & 5 & 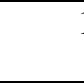 & & 11 \\
\hline $\begin{array}{l}\text { - } \begin{array}{l}\text { znanstveni } \\
\text { savjetnik u trajnom } \\
\text { zvanju }\end{array} \\
\end{array}$ & 3 & 4 & 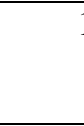 & & 8 \\
\hline $\begin{array}{l}\text { OBRAZLOŽENJE } \\
\text { KATEGORIZACIJE } \\
\text { RADOVA* }\end{array}$ & $\begin{array}{l}\text { a1 - znanstveni radovi } \\
\text { objavljeni u } \\
\text { znanstvenim } \\
\text { časopisima zastupljeni } \\
\text { u bazama podataka } \\
\text { WoSCC ili Scopus }\end{array}$ & $\begin{array}{l}\text { a2- znanstveni } \\
\text { radovi objavljeni u } \\
\text { znanstvenim } \\
\text { časopisima u } \\
\text { drugim, Pravilnikom } \\
\text { definiranim, bazama } \\
\end{array}$ & $\begin{array}{l}\text { a3 }-\mathrm{O} \\
\text { znans } \\
\text { radov }\end{array}$ & & / \\
\hline \multicolumn{5}{|c|}{ NAČIN ODREĐIVANJA BODOVA } & \\
\hline - c članak u časopisu & $\begin{array}{l}\text { Q1 i Q2 - } 2 \text { boda } \\
\text { Q3 i Q4 - 1 bod }\end{array}$ & 0,75 bodova & \multicolumn{2}{|c|}{0,5 bodova } & \\
\hline $\begin{array}{l}\text { članak u zborniku } \\
\text { radova }\end{array}$ & $\begin{array}{l}\text { Q1 i Q2 - } 2 \text { boda } \\
\text { Q3 i Q4-1 bod }\end{array}$ & 0,75 bodova & \multicolumn{2}{|c|}{0,5 bodova } & \\
\hline - poglavlje u knjizi & 1 bod & 0,75 bodova & \multicolumn{2}{|c|}{0,5 bodova } & \\
\hline - $\quad$ knjiga & 3 boda & 2,25 bodova & \multicolumn{2}{|c|}{1,5 bodova } & \\
\hline \multicolumn{6}{|c|}{$\begin{array}{l}\text { *pored navedenih osnovnih uvjeta za kategorizaciju radova na al, a2 i a3 radove Pravilnikom su } \\
\text { definirani i ostali uvjeti pod kojima se radovi mogu klasificirati u navedene kategorije. Također su } \\
\text { definirani i dodatni uvjeti za polje ekonomije. }\end{array}$} \\
\hline \multicolumn{6}{|c|}{$\begin{array}{l}\text { KRITERIJI ZA IZBOR U ZNANSTVENA ZVANJA SUKLADNO STAROM } \\
\text { PRAVILNIKU O UVJETIMA ZA IZBOR U ZNANSTVENA ZVANJA (NN 84/05, } \\
\text { 100/06, 138/06, 42/07, 120/07, 71/10, 116/10, 38/11) }\end{array}$} \\
\hline \multirow[b]{2}{*}{$\begin{array}{c}\text { ZNANSTVENA } \\
\text { ZVANJA }\end{array}$} & \multicolumn{5}{|c|}{ BROJ POTREBNIH RADOVA } \\
\hline & a1 & \multicolumn{2}{|l|}{ a2 } & \multicolumn{2}{|c|}{ Ukupno } \\
\hline $\begin{array}{ll}\text { - } & \text { znanstveni } \\
& \text { suradnik } \\
\end{array}$ & 3 rada & \multicolumn{2}{|l|}{3 rada } & \multicolumn{2}{|c|}{6 radova } \\
\hline $\begin{array}{l}\text { - } \quad \text { viši znanstveni } \\
\text { suradnik }\end{array}$ & 6 radova & \multicolumn{2}{|l|}{8 radova } & \multicolumn{2}{|c|}{$\begin{array}{l}14 \text { radova } \\
(\Delta 3+\Delta 5)\end{array}$} \\
\hline $\begin{array}{ll}\text { - } & \text { znanstveni } \\
\text { savjetnik }\end{array}$ & 10 radova & \multicolumn{2}{|l|}{15 radova } & \multicolumn{2}{|c|}{$\begin{array}{l}25 \text { radova } \\
(\Delta 4+\Delta 7)\end{array}$} \\
\hline $\begin{array}{l}\text { OBRAZLOŽENJE } \\
\text { KATEGORIZACIJE } \\
\text { RADOVA }\end{array}$ & $\begin{array}{c}\text { Radovi objavljeni u } \\
\text { međunarodno priznatim } \\
\text { časopisima i } \\
\text { publikacijama* }\end{array}$ & \multicolumn{2}{|c|}{ Ostali znanstveni radovi } & & / \\
\hline
\end{tabular}


* radovi u publikacijama zastupljenim u Pravilnikom definiranim bazama podataka ili radovi $u$ publikacijama koje imaju međunarodno uredništvo i inozemne recenzente. (Knjiga se vrednuje kao tri rada u odgovarajućoj kategoriji)

Izvor: Pravilnik o uvjetima za izbor u znanstvena zvanja, NN 28/17 i Pravilnik o uvjetima za izbor u znanstvena zvanja, NN 84/05, 100/06, 138/06, 120/07, 71/10, $116 / 10$ i $38 / 11$

Pored navedenog, novim Pravilnikom za polje ekonomije zahtjeva se ispunjenje dodatnih uvjeta, kao npr. pristupnik pri izboru u svako više znanstveno zvanje mora ostvariti najmanje dva boda temeljem radova objavljenih u znanstvenim časopisima zastupljenima u bazama podataka WoSCC ili Scopus te se zahtjeva objava najmanje jednog (za znanstveno zvanje znanstveni suradnik) ili najmanje po dva (za izbor u svako više zvanje) samostalna znanstvena rada objavljena nakon prethodnog izbora itd. što dodatno ukazuje na zahtjevnost procesa napredovanja $i$ potrebu kontinuiranog rada osoba koje žele biti izabrane u određeno znanstveno zvanje.

Ranije je bilo navedeno kako nastavnici trebaju biti birani u znanstveno-nastavna zvanja koji pored odgovarajućeg znanstvenog zvanja zahtijevaju i niz drugih uvjeta za ocjenu nastavne i znanstveno-stručne djelatnosti. Donošenje nužnih uvjeta je u nadležnosti Rektorskoga zbora koji, temeljem odredbi Zakona o znanstvenoj djelatnosti i visokom obrazovanju uz suglasnost Nacionalnoga vijeća za znanost, visoko obrazovanje i tehnologijski razvoj, propisuje minimalne uvjete za napredovanje hrvatskih nastavnika u visokom obrazovanju (tablica 5). 
Tablica 5. Analiza aktualnih uvjeta za ocjenu nastavne i znanstveno-stručne djelatnosti u postupku izbora u znanstveno-nastavna zvanja u znanstvenom području društvenih znanosti

\begin{tabular}{|c|c|c|c|c|c|}
\hline \multicolumn{2}{|r|}{ UVJETI } & Docent & $\begin{array}{l}\text { Izvanred } \\
\text { ni } \\
\text { profesor }\end{array}$ & $\begin{array}{l}\text { Redoviti } \\
\text { profesor }\end{array}$ & $\begin{array}{c}\text { Redoviti } \\
\text { profesor } \\
\text { u } \\
\text { trajnom } \\
\text { zvanju }\end{array}$ \\
\hline \multicolumn{6}{|c|}{$\begin{array}{c}\text { Odluka Rektorskoga zbora o nužnim uvjetima za ocjenu nastavne i } \\
\text { znanstveno-stručne djelatnosti u postupku izbora u znanstveno-nastavna } \\
\text { zvanja (NN, br. 122/17) }\end{array}$} \\
\hline ప̄ & $\begin{array}{l}\text { 1. pozitivno ocijenjeno nastupno } \\
\text { predavanje pred nastavnicima i } \\
\text { studentima za docenta } \\
\text { 2. izvođenje nastave u svojstvu } \\
\text { nastavnika na visokom učilištu u } \\
\text { ukupnom opsegu od: } \\
\text { 3. pozitivno ocijenjeni rezultati } \\
\text { institucijskog istraživanja kvalitete } \\
\text { svog nastavnog rada ili pozitivno } \\
\text { ocijenjene rezultate studentske ankete, } \\
\text { koju provodi visoko učilište }\end{array}$ & - & $\begin{array}{l}\text { Najmanje } \\
300 \\
\text { norma sati }\end{array}$ & $\begin{array}{l}\text { Najmanje } \\
600 \\
\text { norma sati }\end{array}$ & $\begin{array}{l}\text { Najmanje } \\
\quad 900 \\
\text { norma sati }\end{array}$ \\
\hline \multirow{8}{*}{ 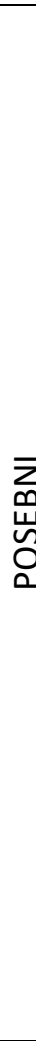 } & Kriterij nastavnog doprinosa & 1 od 10 & $2 \operatorname{od} 10$ & 3 od 10 & 4 od 10 \\
\hline & $\begin{array}{l}\text { 1. uvjet mentorstva ili komentorstva } \\
\text { pri izradi završnih ili diplomskih } \\
\text { radova }\end{array}$ & $\begin{array}{l}\text { najmanje } \\
2 \text { rada }\end{array}$ & $\begin{array}{c}\Delta \\
\text { najmanje } \\
5 \text { radova }\end{array}$ & $\begin{array}{c}\Delta \\
\text { najmanje } \\
5 \text { radova }\end{array}$ & $\begin{array}{c}\Delta \\
\text { najmanje } \\
5 \text { radova }\end{array}$ \\
\hline & $\begin{array}{l}\text { 2. uvjet objavljivanja rada u } \\
\text { koautorstvu sa studentom iz područja } \\
\text { teme završnog ili diplomskog rada }\end{array}$ & $\begin{array}{l}\text { najmanje } \\
1 \mathrm{rad}\end{array}$ & $\begin{array}{c}\Delta \\
\text { najmanje } \\
1 \mathrm{rad}\end{array}$ & $\begin{array}{c}\Delta \\
\text { najmanje } \\
1 \mathrm{rad}\end{array}$ & $\begin{array}{c}\Delta \\
\text { najmanje } \\
1 \mathrm{rad}\end{array}$ \\
\hline & $\begin{array}{l}\text { 3. uvjet usavršavanja u znanstvenom } \\
\text { području ili struci ili nastavi }\end{array}$ & $\begin{array}{l}\text { najmanje } \\
3 \text { mjeseca }\end{array}$ & $\begin{array}{l}\text { najmanje } \\
6 \text { mjeseci }\end{array}$ & $\begin{array}{l}\text { najmanje } \\
9 \text { mjeseci }\end{array}$ & $\begin{array}{l}\text { najmanje } \\
12 \\
\text { mjeseci }\end{array}$ \\
\hline & $\begin{array}{l}\text { 4. uvjet objavljivanja znanstvene } \\
\text { knjige, sveučilišnog udžbenika ili } \\
\text { sveučilišnog priručnika u autorstvu ili } \\
\text { koautorstvu }\end{array}$ & $\begin{array}{l}1 \text { knjiga/ } \\
\text { udžbenik/ } \\
\text { priručnik }\end{array}$ & $\begin{array}{l}\Delta 1 \\
\text { knjiga/ } \\
\text { udžbenik/ } \\
\text { priručnik }\end{array}$ & $\begin{array}{c}\Delta 1 \\
\text { knjiga/ } \\
\text { udžbenik/ } \\
\text { priručnik }\end{array}$ & $\begin{array}{c}\Delta 1 \\
\text { knjiga/ } \\
\text { udžbenik/ } \\
\text { priručnik }\end{array}$ \\
\hline & $\begin{array}{l}\text { 5. uvjet inoviranja nastavnog sadržaja } \\
\text { (izrada novog studijskog } \\
\text { programa/novi kolegij/ nastavni } \\
\text { materijali na webu/ uvođenje novih } \\
\text { nastavnih metoda) } \\
\end{array}$ & $\begin{array}{l}1 \text { od } \\
\text { navedenih } \\
\text { načina }\end{array}$ & $\begin{array}{l}1 \text { od } \\
\text { navedenih } \\
\text { načina }\end{array}$ & $\begin{array}{c}1 \text { od } \\
\text { navedenih } \\
\text { načina }\end{array}$ & $\begin{array}{c}1 \text { od } \\
\text { navedenih } \\
\text { načina }\end{array}$ \\
\hline & $\begin{array}{l}\text { 6. uvjet mentorstva pri izradi } \\
\text { doktorskih disertacija }\end{array}$ & - & $\begin{array}{c}\Delta \\
\text { najmanje } \\
1 \\
\text { disertacija }\end{array}$ & $\begin{array}{c}\Delta \\
\text { najmanje } \\
1 \\
\text { disertacija }\end{array}$ & $\begin{array}{c}\Delta \\
\text { najmanje } \\
1 \\
\text { disertacija }\end{array}$ \\
\hline & $\begin{array}{l}\text { 7. uvjet objavljivanja rada u } \\
\text { koautorstvu sa studentom iz područja }\end{array}$ & - & $\begin{array}{c}\Delta \\
\text { najmanje }\end{array}$ & $\begin{array}{c}\Delta \\
\text { najmanje }\end{array}$ & $\begin{array}{c}\Delta \\
\text { najmanje }\end{array}$ \\
\hline
\end{tabular}



PROFESIJE

\begin{tabular}{|c|c|c|c|c|}
\hline teme doktorskog rada & & $1 \mathrm{rad}$ & $1 \mathrm{rad}$ & $1 \mathrm{rad}$ \\
\hline $\begin{array}{l}\text { 8. uvjet recenziranja studijskih } \\
\text { programa, odnosno članstva u } \\
\text { povjerenstvu za reakreditaciju } \\
\text { studijskih programa }\end{array}$ & $\begin{array}{c}\text { najmanje } \\
1\end{array}$ & $\begin{array}{c}\text { najmanje } \\
1\end{array}$ & $\begin{array}{c}\text { najmanje } \\
1\end{array}$ & $\begin{array}{c}\text { najmanje } \\
1\end{array}$ \\
\hline $\begin{array}{l}\text { 9. uvjet recenziranja znanstvene } \\
\text { knjige, sveučilišnog udžbenika ili } \\
\text { sveučilišnog priručnika }\end{array}$ & $\begin{array}{c}\text { najmanje } \\
1\end{array}$ & $\begin{array}{c}\Delta \\
\text { najmanje } \\
1\end{array}$ & $\begin{array}{c}\Delta \\
\text { najmanje } \\
1\end{array}$ & $\begin{array}{c}\Delta \\
\text { najmanje } \\
1\end{array}$ \\
\hline $\begin{array}{l}\text { 10. uvjet koordiniranja suradnje s } \\
\text { nastavnim bazama }\end{array}$ & $\begin{array}{l}\text { najmanje } \\
1\end{array}$ & $\begin{array}{l}\text { najmanje } \\
1\end{array}$ & $\begin{array}{l}\text { najmanje } \\
1\end{array}$ & $\begin{array}{l}\text { najmanje } \\
1\end{array}$ \\
\hline $\begin{array}{c}\text { Kriterij znanstveno-stručnog } \\
\text { doprinosa }\end{array}$ & 1 od 11 & 2 od 11 & 3 od 11 & $4 \operatorname{od} 11$ \\
\hline $\begin{array}{l}\text { 1. Uvjet prezentiranja radova na } \\
\text { znanstvenim ili stručnim skupovima } \\
\text { (domaćim i međunarodnim) }\end{array}$ & $\begin{array}{l}\text { najmanje } \\
3 \text { rada }\end{array}$ & $\begin{array}{c}\Delta \\
\text { najmanje } \\
5 \text { (barem } \\
2 \text { na } \\
\text { stranom } \\
\text { jeziku) }\end{array}$ & $\begin{array}{c}\Delta \\
\text { najmanje } \\
5 \text { (barem } \\
2 \text { na } \\
\text { stranom } \\
\text { jeziku) }\end{array}$ & $\begin{array}{c}\Delta \\
\text { najmanje } \\
5 \text { (barem } \\
2 \text { na } \\
\text { stranom } \\
\text { jeziku) } \\
\end{array}$ \\
\hline $\begin{array}{l}\text { 2. Uvjet pozvanog predavanja na } \\
\text { međunarodnom znanstvenom ili } \\
\text { stručnom skupu }\end{array}$ & $\begin{array}{c}\text { najmanje } \\
1\end{array}$ & $\begin{array}{c}\Delta \\
\text { najmanje } \\
1\end{array}$ & $\begin{array}{c}\Delta \\
\text { najmanje } \\
1\end{array}$ & $\begin{array}{c}\Delta \\
\text { najmanje } \\
1\end{array}$ \\
\hline $\begin{array}{l}\text { 3. Uvjet vođenja ili sudjelovanja u } \\
\text { realizaciji znanstveno-istraživačkih } \\
\text { projekata MZOS-a }\end{array}$ & $\begin{array}{l}\text { sudjelova } \\
\text { nje u } \\
\text { najmanje } \\
1\end{array}$ & $\begin{array}{l}\text { vođenje } \\
\text { najmanje } \\
1\end{array}$ & $\begin{array}{l}\text { vođenje } \\
\text { najmanje } \\
1\end{array}$ & $\begin{array}{c}\text { vođenje } \\
\text { najmanje } \\
1\end{array}$ \\
\hline $\begin{array}{l}\text { 4. Uvjet vođenja ili sudjelovanja u } \\
\text { realizaciji znanstvenog programa } \\
\text { znanstvenih centara izvrsnosti, } \\
\text { europskih i međunarodnih } \\
\text { kompetitivnih projekta i projekata } \\
\text { Hrvatske zaklade za znanost }\end{array}$ & $\begin{array}{c}\text { sudjelova } \\
\text { nje/vođen } \\
\text { je } \\
\text { najmanje } \\
1\end{array}$ & $\begin{array}{c}\text { sudjelova } \\
\text { nje/vođen } \\
\text { je } \\
\text { najmanje } \\
1\end{array}$ & $\begin{array}{c}\text { sudjelova } \\
\text { nje/vođen } \\
\text { je } \\
\text { najmanje } \\
1\end{array}$ & $\begin{array}{c}\text { sudjelova } \\
\text { nje/vođen } \\
\text { je } \\
\text { najmanje } \\
1\end{array}$ \\
\hline 5. Uvjet uređivanja zbornika & $\begin{array}{c}\text { najmanje } \\
1\end{array}$ & $\begin{array}{c}\text { najmanje } \\
1\end{array}$ & $\begin{array}{c}\text { najmanje } \\
1\end{array}$ & $\begin{array}{c}\text { najmanje } \\
1 \\
\end{array}$ \\
\hline $\begin{array}{l}\text { 6. Uvjet recenziranja članaka u } \\
\text { časopisima i zbornicima }\end{array}$ & $\begin{array}{l}\text { najmanje } \\
3 \text { članka }\end{array}$ & $\begin{array}{c}\Delta \\
\text { najmanje } \\
5 \text { članaka }\end{array}$ & $\begin{array}{c}\Delta \\
\text { najmanje } \\
5 \text { članaka }\end{array}$ & $\begin{array}{c}\Delta \\
\text { najmanje } \\
5 \text { članaka }\end{array}$ \\
\hline 7. Uvjet recenziranja projekata & $\begin{array}{c}\text { najmanje } \\
1\end{array}$ & $\begin{array}{c}\text { najmanje } \\
1\end{array}$ & $\begin{array}{c}\text { najmanje } \\
1\end{array}$ & $\begin{array}{c}\text { najmanje } \\
1\end{array}$ \\
\hline $\begin{array}{l}\text { 8. Uvjet članstva u organizacijskom ili } \\
\text { programskom odboru znanstvenog } \\
\text { skupa }\end{array}$ & $\begin{array}{c}\text { najmanje } \\
1\end{array}$ & $\begin{array}{c}\text { najmanje } \\
1\end{array}$ & $\begin{array}{c}\text { najmanje } \\
1\end{array}$ & $\begin{array}{c}\text { najmanje } \\
1\end{array}$ \\
\hline 9. Uvjet objavljivanja stručnih radova & $\begin{array}{l}\text { najmanje } \\
3 \text { članka }\end{array}$ & $\begin{array}{c}\Delta \\
\text { najmanje } \\
3 \text { članka } \\
\end{array}$ & $\begin{array}{c}\Delta \\
\text { najmanje } \\
3 \text { članka } \\
\end{array}$ & $\begin{array}{c}\Delta \\
\text { najmanje } \\
3 \text { članka }\end{array}$ \\
\hline $\begin{array}{l}\text { 10. Uvjet dobivanja međunarodne ili } \\
\text { istaknute domaće nagrade ili priznanja } \\
\text { za znanstveni, nastavni ili stručni rad }\end{array}$ & $\begin{array}{l}\text { najmanje } \\
1\end{array}$ & $\begin{array}{c}\text { najmanje } \\
1\end{array}$ & $\begin{array}{c}\text { najmanje } \\
1\end{array}$ & $\begin{array}{c}\text { najmanje } \\
1\end{array}$ \\
\hline 11. Uvjet sudjelovanja u programima & najmanje & najmanje & najmanje & najmanje \\
\hline
\end{tabular}




\begin{tabular}{|c|c|c|c|c|}
\hline popularizacije znanosti & 1 & 1 & 1 & 1 \\
\hline Kriterij institucijskog doprinosa & o od 11 & o od 11 & 1 od 11 & 2 od 11 \\
\hline 1. Uvjet obnašanja čelne dužnosti & $\begin{array}{c}\text { najmanje } \\
1 \\
\end{array}$ & $\begin{array}{c}\text { najmanje } \\
1 \\
\end{array}$ & $\begin{array}{c}\text { najmanje } \\
1 \\
\end{array}$ & $\begin{array}{c}\text { najmanje } \\
1 \\
\end{array}$ \\
\hline $\begin{array}{l}\text { 2. Uvjet obnašanja voditeljske } \\
\text { dužnosti na ustrojbenoj jedinici } \\
\text { visokog učilišta }\end{array}$ & $\begin{array}{l}\text { najmanje } \\
1\end{array}$ & $\begin{array}{l}\text { najmanje } \\
1\end{array}$ & $\begin{array}{c}\text { najmanje } \\
1\end{array}$ & $\begin{array}{c}\text { najmanje } \\
1\end{array}$ \\
\hline $\begin{array}{l}\text { 3. Uvjet članstva u sveučilišnim } \\
\text { tijelima i voditeljstva u tijelima na } \\
\text { sastavnici }\end{array}$ & $\begin{array}{l}\text { najmanje } \\
1\end{array}$ & $\begin{array}{l}\text { najmanje } \\
1\end{array}$ & $\begin{array}{l}\text { najmanje } \\
1\end{array}$ & $\begin{array}{c}\text { najmanje } \\
1\end{array}$ \\
\hline $\begin{array}{l}\text { 4. Uvjet vođenja ili sudjelovanja u } \\
\text { realizaciji sveučilišnih razvojnih } \\
\text { projekata ili drugih stručnih projekta }\end{array}$ & $\begin{array}{l}\text { najmanje } \\
1\end{array}$ & $\begin{array}{l}\text { najmanje } \\
1\end{array}$ & $\begin{array}{c}\text { najmanje } \\
1\end{array}$ & $\begin{array}{c}\text { najmanje } \\
1\end{array}$ \\
\hline $\begin{array}{l}\text { 5. Uvjet sudjelovanja u vođenju } \\
\text { alumni udruga }\end{array}$ & $\begin{array}{c}\text { najmanje } \\
1\end{array}$ & $\begin{array}{c}\text { najmanje } \\
1\end{array}$ & $\begin{array}{c}\text { najmanje } \\
1\end{array}$ & $\begin{array}{c}\text { najmanje } \\
1\end{array}$ \\
\hline $\begin{array}{l}\text { 6. Uvjet sudjelovanja u izradi i/ili } \\
\text { izvedbi programa cjeloživotnog } \\
\text { obrazovanja }\end{array}$ & $\begin{array}{l}\text { najmanje } \\
1\end{array}$ & $\begin{array}{l}\text { najmanje } \\
1\end{array}$ & $\begin{array}{c}\text { najmanje } \\
1\end{array}$ & $\begin{array}{c}\text { najmanje } \\
1\end{array}$ \\
\hline $\begin{array}{l}\text { 7. Uvjet sudjelovanja u izradi i } \\
\text { izvedbi programa transfera znanja i } \\
\text { tehnologije }\end{array}$ & $\begin{array}{l}\text { najmanje } \\
1\end{array}$ & $\begin{array}{l}\text { najmanje } \\
1\end{array}$ & $\begin{array}{c}\text { najmanje } \\
1\end{array}$ & $\begin{array}{c}\text { najmanje } \\
1\end{array}$ \\
\hline $\begin{array}{l}\text { 8. Uvjet članstva u međunarodnim ili } \\
\text { nacionalnim tijelima za znanost i } \\
\text { visoko obrazovanje }\end{array}$ & $\begin{array}{c}\text { najmanje } \\
1\end{array}$ & $\begin{array}{l}\text { najmanje } \\
1\end{array}$ & $\begin{array}{c}\text { najmanje } \\
1\end{array}$ & $\begin{array}{c}\text { najmanje } \\
1\end{array}$ \\
\hline $\begin{array}{l}\text { 9. Uvjet članstva u uredništvu } \\
\text { znanstvenih i stručnih časopisa }\end{array}$ & $\begin{array}{c}\text { najmanje } \\
1 \\
\end{array}$ & $\begin{array}{c}\text { najmanje } \\
1 \\
\end{array}$ & $\begin{array}{c}\text { najmanje } \\
1 \\
\end{array}$ & $\begin{array}{c}\text { najmanje } \\
1 \\
\end{array}$ \\
\hline $\begin{array}{l}\text { 10. Uvjet dobivanja nagrade ili } \\
\text { priznanja akademskih institucija i } \\
\text { udruga }\end{array}$ & $\begin{array}{c}\text { najmanje } \\
1\end{array}$ & $\begin{array}{c}\text { najmanje } \\
1\end{array}$ & $\begin{array}{c}\text { najmanje } \\
1\end{array}$ & $\begin{array}{c}\text { najmanje } \\
1\end{array}$ \\
\hline
\end{tabular}

Izvor: Obrada autora prema Odluci o nužnim uvjetima za ocjenu nastavne i znanstveno-stručne djelatnosti u postupku izbora u znanstveno-nastavna zvanja, NN 122/17

U tablici 5. prikazani su nužni uvjeti vrednovanja nastavne i znanstveno-stručne djelatnosti koji obuhvaćaju tri razine što podrazumijeva vrednovanje nastavnog, znanstveno-stručnog i institucijskog doprinosa. Sukladno Odluci o nužnim uvjetima za ocjenu nastavne i znanstveno-stručne djelatnosti (NN 122/17) svaki nastavnik koji želi biti izabran u nastavno-znanstveno zvanje mora ispuniti sve opće i minimalni broj posebnih uvjeta. Pristupnici koji se po prvi puta izabiru u znanstveno-nastavno zvanje docenta pored znanstvenog zvanja moraju imati pozitivno ocijenjeno nastupno predavanje pred nastavnicima i studentima. Za izbor u svako više znanstveno-nastavno zvanje zahtijeva se izvođenje nastave u svojstvu nastavnika na visokom učilištu u ukupnom opsegu od 300, 600 ili 900 norma sati ovisno o zvanju te se zahtjeva da njihov nastavni rad bude pozitivno ocijenjen od strane studenata. Posebni uvjeti obuhvaćaju tri razine vrednovanja (nastavna djelatnost, znanstveno-stručna te institucijska aktivnost) rada nastavnika. 
Uspoređujući aktualne uvjete s prijašnjim (tablica 6) vidljivo je da su posebni uvjeti drugačije kategorizirani te da je značajno proširen spektar potrebnih uvjeta za mjerenje doprinosa nastavnika. Posebna novina je vrednovanje institucijskog doprinosa koji podrazumijeva znanstveno-stručni doprinos nastavnika u djelovanju sveučilišnih i drugih akademskih institucija koji se zahtijeva za najviša zvanja, zvanje redovitog profesora odnosno redovitog profesora u trajnom zvanju.

Tablica 6. Analiza prijašnjih uvjeta za ocjenu nastavne i znanstveno-stručne djelatnosti u postupku izbora u znanstveno-nastavna zvanja u znanstvenom području društvenih znanosti

\begin{tabular}{|c|c|c|c|c|c|}
\hline \multicolumn{6}{|c|}{$\begin{array}{l}\text { Odluka o nužnim uvjetima za ocjenu nastavne i stručne djelatnosti u } \\
\text { postupku izbora } \\
\text { u znanstveno-nastavna zvanja, NN 106/06 }\end{array}$} \\
\hline & UVJETI & Docent & $\begin{array}{l}\text { Izvanred } \\
\text { ni } \\
\text { profesor }\end{array}$ & $\begin{array}{l}\text { Redoviti } \\
\text { profesor }\end{array}$ & $\begin{array}{c}\text { Redoviti } \\
\text { profesor } \\
\text { u } \\
\text { trajnom } \\
\text { zvanju } \\
\end{array}$ \\
\hline $\begin{array}{l}\mathbf{O} \\
\mathbf{P} \\
\text { Ć } \\
\mathbf{I}\end{array}$ & $\begin{array}{l}\text { 1. pozitivno ocijenjeno nastupno } \\
\text { predavanje pred nastavnicima i } \\
\text { studentima za docenta } \\
\text { 2. izvođenje nastave u svojstvu } \\
\text { nastavnika na visokom učilištu u } \\
\text { ukupnom opsegu od: } \\
\text { 3. pozitivno ocijenjeni rezultati } \\
\text { institucijskog istraživanja kvalitete } \\
\text { svog nastavnog rada ili pozitivno } \\
\text { ocijenjene rezultate studentske ankete, } \\
\text { koju provodi visoko učilište }\end{array}$ & $\begin{array}{l}\text { Najmanje } \\
90 \text { norma } \\
\text { sati }\end{array}$ & $\begin{array}{l}\text { Najmanje } \\
300 \\
\text { norma sati }\end{array}$ & $\begin{array}{l}\text { Najmanje } \\
\quad 600 \\
\text { norma sati }\end{array}$ & - \\
\hline \multirow{6}{*}{$\begin{array}{c}\mathbf{P} \\
\mathbf{O} \\
\mathrm{S} \\
\mathrm{E} \\
\mathbf{B} \\
\mathbf{N} \\
\text { I }\end{array}$} & Kriteriji & 1 od 3 & 3 od 6 & 4 od 8 & 6 od 12 \\
\hline & $\begin{array}{l}\text { 1. uvjet mentorstva pri izradi završnih } \\
\text { ili diplomskih radova te uvjet } \\
\text { objavljivanja rada u koautorstvu sa } \\
\text { studentom }\end{array}$ & $\begin{array}{l}\text { najmanje } \\
\quad 1 \\
\text { mentorstv } \\
\text { o i } 1 \text { rad }\end{array}$ & $\begin{array}{l}\text { najmanje } \\
7 \\
\text { mentorstv } \\
\text { a i } 2 \text { rada }\end{array}$ & $\begin{array}{l}\text { najmanje } \\
10 \\
\text { mentorstv } \\
\text { a i } 4 \text { rada }\end{array}$ & $\begin{array}{l}\text { najmanje } \\
10 \\
\text { mentorstv } \\
\text { a i } 4 \text { rada }\end{array}$ \\
\hline & $\begin{array}{l}\text { 2. uvjet usavršavanja u znanstvenom } \\
\text { području ili struci ili nastavi }\end{array}$ & $\begin{array}{l}\text { najmanje } \\
3 \text { mjeseca }\end{array}$ & $\begin{array}{l}\text { najmanje } \\
1 \text { godina }\end{array}$ & $\begin{array}{l}\text { najmanje } \\
2 \text { godine }\end{array}$ & $\begin{array}{l}\text { najmanje } \\
2 \text { godine }\end{array}$ \\
\hline & $\begin{array}{l}\text { 3. uvjet prezentiranja radova na } \\
\text { znanstvenim ili stručnim skupovima } \\
\text { (domaćim i međunarodnim) }\end{array}$ & $\begin{array}{c}\text { najmanje } \\
3 \text { rada } \\
\text { (barem } 1 \\
\text { na } \\
\text { stranom } \\
\text { jeziku) }\end{array}$ & $\begin{array}{l}\text { najmanje } \\
5 \text { (barem } \\
2 \text { na } \\
\text { stranom } \\
\text { jeziku) }\end{array}$ & $\begin{array}{c}\text { najmanje } \\
7 \text { (barem } \\
4 \text { na } \\
\text { stranom } \\
\text { jeziku) }\end{array}$ & $\begin{array}{c}\text { najmanje } \\
7 \text { (barem } \\
4 \text { na } \\
\text { stranom } \\
\text { jeziku) }\end{array}$ \\
\hline & $\begin{array}{l}\text { 4. autor/koautor sveučilišnog } \\
\text { udžbenika, znanstvene knjige ili } \\
\text { priručnika tj. na web stranici postavio } \\
\text { svoja predavanja kao nastavni tekst }\end{array}$ & - & $\begin{array}{c}\text { najmanje } \\
1\end{array}$ & $\begin{array}{l}\text { najmanje } \\
2\end{array}$ & $\begin{array}{l}\text { najmanje } \\
2\end{array}$ \\
\hline & 5. uvjet inoviranja ili uvođenja novog & - & najmanje & najmanje & najmanje \\
\hline
\end{tabular}




\begin{tabular}{|c|c|c|c|c|}
\hline $\begin{array}{l}\text { nastavnog sadržaja (sadržaj } \\
\text { kolegija/uvođenje novih nastavnih } \\
\text { metoda) }\end{array}$ & & 1 & 1 & 1 \\
\hline $\begin{array}{l}\text { 6. uvjet mentorstva pri izradi } \\
\text { doktorskog rada te uvjet objavljivanja } \\
\text { rada u koautorstvu sa studentom }\end{array}$ & - & $\begin{array}{c}\text { najmanje } \\
1\end{array}$ & $\begin{array}{c}\text { najmanje } \\
2\end{array}$ & $\begin{array}{c}\text { najmanje } \\
2\end{array}$ \\
\hline $\begin{array}{l}\text { 7. uvjet članstva uređivačkog odbora } \\
\text { znanstvenog časopisa ili uređivanje } \\
\text { zbornika radova znanstvenih skupova }\end{array}$ & - & - & $\begin{array}{l}\text { najmanje } \\
4 \text { godine } \\
\text { ili barem } \\
2 \\
\text { zbornika }\end{array}$ & $\begin{array}{c}\text { najmanje } \\
4 \text { godine } \\
\text { ili barem } \\
2 \\
\text { zbornika }\end{array}$ \\
\hline 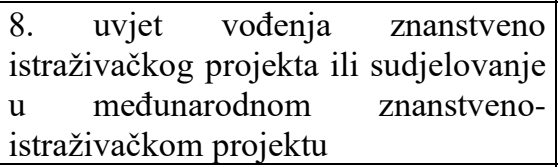 & - & - & $\begin{array}{c}\text { najmanje } \\
1\end{array}$ & $\begin{array}{c}\text { najmanje } \\
1\end{array}$ \\
\hline $\begin{array}{l}\text { 9. pozvani predavač na } \\
\text { međunarodnom znanstvenom skupu }\end{array}$ & - & - & - & $\begin{array}{c}\text { najmanje } \\
2 \\
\end{array}$ \\
\hline $\begin{array}{l}\text { 10. uvjet recenziranja } \\
\text { programa ili stujeučilišnogih } \\
\text { ili znanstvene knjige }\end{array}$ & - & - & - & $\begin{array}{c}\text { najmanje } \\
2\end{array}$ \\
\hline $\begin{array}{l}\text { 11. obnašanje čelne dužnosti u } \\
\text { strukovnoj asocijaciji ili na visokom } \\
\text { učilištu ili široj akademskoj zajednici }\end{array}$ & - & - & - & $\begin{array}{c}\text { najmanje } \\
1\end{array}$ \\
\hline $\begin{array}{l}\text { 12. uvjet dobivanja nagrade za } \\
\text { znanstveni ili nastavni rad }\end{array}$ & - & - & - & $\begin{array}{c}\text { najmanje } \\
1\end{array}$ \\
\hline
\end{tabular}

Izvor: Obrada autora prema Odluci o nužnim uvjetima za ocjenu nastavne i stručne djelatnosti u postupku izbora u znanstveno-nastavna zvanja, NN 106/06

Iz navedenih uvjeta vidljivo je da posao sveučilišnih nastavnika nisu samo predavanja već da, osim predavanja, postoji široki spektar aktivnosti koje obuhvaćaju i znanstvena istraživanja, rad na znanstvenim i stručnim projektima, međunarodnu uključenost i suradnju sa relevantnim znanstvenim i stručnim institucijama, doprinos društvenoj zajednici kroz aktivno uključivanje u različite druge aktivnosti koje indirektno doprinose novim spoznajama i širini znanja i kompetencija koje sveučilišni nastavnici mogu posjedovati. Cjelina svih tih znanja nastalih kroz kontinuirao obrazovanje i aktivnu uključenost $u$ znanstvenu i društvenu zajednicu zasigurno doprinosi i kvaliteti predavanja i prijenosu znanja na nove generacije budućih poslovnih ljudi. Vezano uz obrazovanje računovođa odnosno ishode učenja i izlazne kompetencije $\mathrm{s}$ kojima studenti, budući računovođe, izlaze na tržište rada, potrebno je istaknuti da njihovi edukatori odnosno nastavnici koji im prenose stručna znanja također moraju zadovoljiti sve navedene uvjete izbora u znanstveno-nastavna zvanja. Dodatno, potrebno je također istaknuti da su predavači računovodstvenih kolegija na fakultetima posebno aktivni u brojnim nenastavnim aktivnostima kao što je suradnja sa stručnim udruženjima računovođa, članstvo u uredničkim odborima znanstvenih i stručnih časopisa, uredništvo stručnih časopisa i publikacija iz područja 
računovodstva, članstvo u radnim skupinama za donošenje zakona, članstvo u najvišim regulatornim tijelima, kao npr. članstvo u Odboru za standarde financijskog izvještavanja, članstvo u revizorskim i nadzornim odborima, vodstvo znanstvenih i stručnih projekata, organizacija znanstvenih i stručnih skupova, pozvana predavanja na simpozijima i stručnim edukacijama koje organiziraju profesionalna udruženja računovođa itd. Sve navedeno dodatno doprinosi razini i kvaliteti znanja koje sveučilišni nastavnici prenose na generacije računovođa.

U cilju saznanja prate li ovdje navedeni kriteriji napredovanja nastavnika kriterije izvrsnosti znanstveno-istraživačke te nastavne aktivnosti nastavnika visokog obrazovanja država u okruženju, u nastavku rada je komparativnom analizom dana usporedba regulatornog okvira znanstveno-nastavnoga djelovanja nastavnika u području društvenih znanosti - polju ekonomije između Republike Hrvatske i Bosne i Hercegovine.

\subsection{Sustav visokog obrazovanja i kriteriji napredovanja znanstveno- nastavnih djelatnika na visokim učilištima u Bosni i Hercegovini}

Visoko obrazovanje u Bosni i Hercegovini regulirano je primarno Okvirnim zakonom o visokom obrazovanju u Bosni i Hercegovini (Službeni glasnik BiH, broj 59/07, 59/09). Navedeni Zakon definira način organizacije visokog obrazovanja u Bosni i Hercegovini, odgovornost nadležnih vlasti u ovom području, utvrđuje koja su tijela zadužena za provedbu zakona i međunarodnih obveza te države. Pored navedenog, zakon definira načine osiguranja kvalitete u području visokog obrazovanja. U cilju razumijevanja sustava visokog obrazovanja Bosne i Hercegovine ukratko je opisan način organizacije visokih učilišta kao i razine studijskih programa koji se izvode u tri ciklusa. Visokoškolske ustanove u Bosni i Hercegovini kao i u Hrvatskoj čine sveučilišta i visoke škole. Sveučilišta su visokoškolske ustanove koje se bave nastavnim i istraživačkim radom te nude obrazovanje za stjecanje svih akademskih zvanja (od prvostupnika, magistra do doktora znanosti) i to „s ciljem unapređenja znanja, misli i školstva u Bosni i Hercegovini, obrazovni, kulturni, društveni i ekonomski razvoj Bosne i Hercegovine, promoviranje demokratskog građanskog društva i postizanje najviših standarda nastave i istraživačkog rada" (Okvirni zakon o visokom obrazovanju u Bosni i Hercegovini, PSBiH 59/07, 59/09). S druge strane, istim Okvirnim zakonom o visokom obrazovanju (2007) visoke škole su definirane kao one visokoškolske ustanove koje su ovlaštene organizirati studije prvog ciklusa, „s ciljevima koji uključuju pripremu i obuku pojedinaca za stručni, ekonomski i kulturni razvoj Bosne i Hercegovine i promociju demokratskog građanskog društva, te postizanja visokih standarda nastave i učenja.“

Visokoškolske ustanove ovlaštene su dodjeljivati akademska zvanja. Sveučilišta dodjeljuju znanstveno nastavna i umjetnička zvanja (asistent, viši asistent, lektor, docent, izvanredni profesor i redovni profesor) dok visoke škole dodjeljuju 
nastavna i umjetnička zvanja (asistent, predavač visoke škole, profesor visoke škole). Iako postoje određene sličnosti u organizaciji studija te naziva znanstvenonastavnih zvanja naših nastavnika i akademskog osoblja u Bosni i Hercegovini, ipak postoje stanovite razlike u primjeni odgovarajućih propisa. Navedene razlike primarno proizlaze zbog drugačijeg ustroja države i činjenice kako se Bosna i Hercegovina sastoji od dva entiteta, Federacije Bosne i Hercegovine i Republike Srpske i Distrikta Brčko. S obzirom na ovu činjenicu, valja naglasiti kako svaki kanton u pravilu ima svoj Zakon o visokom obrazovanju koji se naslanja na ranije spomenuti Okvirni zakon o visokom obrazovanju. Obzirom na brojnost kantona, a time i zakona o visokom obrazovanju, u nastavku su analizirani isključivo minimalni uvjeti za izbor akademskog osoblja u znanstveno-nastavna zvanja propisani Okvirnim Zakonom i to kako slijedi:

- „asistent: odgovarajući sveučilišni stupanj s najmanje 240 ECTS bodova i najnižom prosječnom ocjenom 8 ili 3,5;

- $\quad$ viši asistent: stupanj drugog ciklusa (magisterij);

- lektor: stupanj drugog ciklusa (magisterij);

- docent: znanstveni stupanj doktora u danom području, najmanje tri znanstvena rada objavljena $u$ priznatim publikacijama, pokazane nastavničke sposobnosti;

- $\quad$ izvanredni profesor: provedeno najmanje jedno izborno razdoblje u zvanju docenta, te najmanje pet objavljenih znanstvenih radova $\mathrm{u}$ priznatim publikacijama, objavljena knjiga i originalni stručni uspjeh, kao što je projekt, patent ili originalna metoda, sve nakon izbora u zvanje docenta, mentorstvo kandidata za stupanj drugog ciklusa;

- redoviti profesor: provedeno najmanje jedno izborno razdoblje u zvanju izvanrednog profesora, najmanje dvije objavljene knjige, najmanje osam objavljenih znanstvenih radova u priznatim publikacijama, sve nakon stjecanja zvanja izvanrednog profesora te uspješno mentorstvo kandidata za stupanj drugog i trećeg ciklusa.“

I iz ovog sažetog prikaza vidljivo je da je rad i djelovanje sveučilišnih nastavnika regulirana aktivnost te da je za stjecanje svakog pojedinog zvanja potrebno ostvariti određene, zakonom i drugim propisima, definirane uvjete. Svaka država ima svoje specifičnosti koje treba uvažiti prilikom analize kvalitete rada nastavnika kao i izlaznih kompetencija stručnjaka koji iz visokoškolskih institucija izlaze na tržište rada. Ovo je posebno važno u kontekstu priznavanja diploma kao i međunarodne mobilnosti radne snage. Stoga uvjetima stjecanja određenih znanja treba posvetiti dužnu pažnju. Pri tome i kvaliteta i educiranost edukatora ima posebno važnu ulogu. Navedeno sve više dolazi do izražaja u uvjetima sve naglašenijih međunarodnih akreditacija temeljem kojih visokoškolske ustanove, kao i osobe koje su na takvim institucijama stekle diplomu mogu ostvariti brojne benefite. 


\section{ZAKLJUČAK}

Sustav visokoškolskog obrazovanja je organiziran i reguliran sustav koji putem kvalitetnih studijskih programa unaprjeđuje postojeći sustav obrazovanja te doprinosi kvaliteti izlaznih kompetencija osoba koji izlaze na tržište rada. Pored kvalitete studijskih programa posebno su važne i nastavničke kompetencije visokoškolskih djelatnika koji svoja stručna znanja prenose studentima koji će ih trebati primjenjivati u svojoj poslovnoj praksi. U tom smislu bilo je važno sagledati koji su to uvjeti i kriteriji koji potiču izvrsnost u poučavanju te prenošenju stručnih znanja budućim generacijama profesionalnih računovođa. Trenutno u Republici Hrvatskoj ne postoji zakonska obveza certificiranja odnosno licenciranja računovodstvenih zvanja i stoga se može reći da je kvaliteta rada računovodstvenih djelatnika u takvim okolnostima primarno determinirana stečenim profesionalnim kompetencijama u okviru formalnog obrazovanja.

U postojećem obrazovnom sustavu kvaliteta rada nastavnika visokog obrazovanja mjeri se kriterijima za izbor u znanstveno-nastavna zvanja koji, s jedne strane, vrednuju njegov znanstveni rad te, s druge strane, posebno vrednuju nastavnu i stručnu djelatnost nastavnika kao i njihov institucijski doprinos. U radu su analizirani kriteriji izvrsnosti nastavnika ekonomske struke $u$ područjima kontinuiranog učenja, poučavanja i sudjelovanja u znanstvenim istraživanjima. Na temelju rezultata provedenog istraživanja moguće je potvrditi činjenicu kako su postojeći kriteriji napredovanja značajno unaprijeđeni te zasigurno potiču visokoškolske djelatnike na kontinuirano učenje i stjecanje novih znanja čime se dodatno razvija znanstveno-istraživački potencijal visokoškolskih nastavnika. To se između ostalog odnosi i na nastavnike računovodstvenih kolegija koji su posebno aktivni u nastavnom, ali i u svom znanstvenom i stručnom radu. Budući da se u sustavu visokoškolskog obrazovanja generira najveći i najznačajniji broj računovodstvenih djelatnika može se potvrditi kako regulatorni okvir znanstvenonastavnoga djelovanja visokoškolskih djelatnika značajno doprinosi i kvaliteti rada računovodstvene profesije. 


\section{LITERATURA}

1. Agencija za znanost i visoko obrazovanje (2018) Visoko obrazovanje u Republici Hrvatskoj: Vodič za članove stručnih povjerenstava u postupcima vrednovanja visokih učilišta i znanstvenih organizacija. Zagreb: AZVO. Dostupno na: https://www.azvo.hr/images/stories /novosti/Bro\%C5\%A1ura_Visoko_obrazovanje_u_RH.pdf (30.06.2019.)

2. Agencija za znanost i visoko obrazovanje (2019) Znanstvene organizacije. Dostupno na: https://www.azvo.hr/hr/znanost/znanstvene-organizacije (30.06.2019.)

3. Državni zavod za statistiku (2018) Proračunska izdvajanja za istraživanje i razvoj, 2017. - 2018. godina. Dostupno na: https://www.dzs. hr/Hrv_Eng/publication/2018/08-02-02_01_2018.htm (30.06.2019.)

4. IAESB (2015) Handbook of International Education Pronouncements. IFAC: International Accounting Education Standards Board.

5. Leksikografski zavod Miroslav Krleža. Dostupno na: http://www.enciklopedija.hr/natuknica.aspx?id=67353 (30.06.2019.)

6. Ministarstvo znanosti i obrazovanja (2019) Programsko financiranje visokih učilišta. Dostupno na: https://mzo.gov.hr/UserDocs Images//dokumenti/Vijesti/2019/2019//Programsko\%20financiranje\%20vis okih\%20u\%C4\%8Dili\%C5\%A1 ta.pdf (24.08.2019.)

7. Ministarstvo znanosti, obrazovanja i sporta (2014) Strategija obrazovanja, znanosti i tehnologije. Dostupno na: https://mzo.gov.hr/UserDocs Images/dokumenti/Obrazovanje/Strategija\%20obrazovanja,\%20znanosti\% 20i\%20tehnologije.pdf (30.06.2019.)

8. Odluka o nužnim uvjetima za ocjenu nastavne i stručne djelatnosti u postupku izbora u znanstveno-nastavna zvanja. Narodne novine 106/06

9. Odluka o nužnim uvjetima za ocjenu nastavne i znanstveno-stručne djelatnosti u postupku izbora u znanstveno-nastavna zvanja. Narodne novine $122 / 17$

10. Okvirni zakon o visokom obrazovanju u Bosni i Hercegovini. Službeni glasnik $\mathrm{BiH}, 59 / 07,59 / 09$

11. Pravilnik o uvjetima za izbor u znanstvena zvanja. Narodne novine $84 / 05$, 100/06, 138/06, 120/07, 71/10, 116/10 i 38/11

12. Pravilnik o uvjetima za izbor u znanstvena zvanja, Narodne novine $28 / 17$

13. Zakon o računovodstvu. Narodne novine $78 / 15$

14. Zakon o znanstvenoj djelatnosti i visokom obrazovanju. Narodne novine 123/03, 105/04, 174/04, 2/07 - Odluka Ustavnog suda Republike Hrvatske, 46/07, 45/09, 63/11, 94/13, i 139/13

15. Žager, K., Dečman, N., Rep A. (2015) Visokoškolsko obrazovanje kao temelj računovodstvene profesije. Računovodstvo i financije, LXII (6), 817. 
16. Žager, K., Sever Mališ, S., Dečman, N. (2016) Certificiranje i licenciranje računovodstvenih i revizijskih zvanja. Zbornik radova (Journal of Economy and Business), Special Issues, 391-420. 


\section{Katarina Žager, PhD}

Faculty of Economics and Business, University of Zagreb, Zagreb, Croatia kzager@efzg.hr

\section{Nikolina Dečman, PhD}

Faculty of Economics and Business, University of Zagreb, Zagreb, Croatia ndecman@efzg.hr

\section{Ana Rep, MA}

Faculty of Economics and Business, University of Zagreb, Zagreb, Croatia arep@efzg.hr

\section{IMPACT OF THE REGULATORY FRAMEWORK OF SCIENTIFIC-TEACHING ACTIVITIES OF HIGHER EDUCATION EMPLOYEES ON THE QUALITY OF ACCOUNTING PROFESSION}

Received: July 15, 2019

Accepted: October 1, 2019

Review

\section{Abstract}

Knowledge is the most valuable resource acquired through education and experience. Although there are many types and therefore definitions of knowledge, it can be said that it involves a theoretical and practical understanding of a particular issue. Scientifically based attitudes form the basis for development of theory, which is then confirmed and further developed in practice. Professional knowledge is primarily acquired in the formal education system and upgraded with continuous training in business practice. It can be said that the education system is the first step in a development of professional competencies of experts in any field, including the field of accounting. A high-quality specialist in accounting requires, above all, a high-quality background in terms of knowledge and skills necessary to understand business processes, as well as the wider field of accounting and auditing that is acquired primarily in higher education institutions. The quality of work of an educational institution, as well as the learning outcomes that students acquire in certain studies, is determined by the quality of study programs and, in particular, by the quality of teaching staff. Considering the fact that one of the most important prerequisites for quality education of future accountants is quality of higher education teachers, it is important to consider what are the conditions and criteria that encourage excellence in teaching and transferring professional knowledge to future generations of professional accountants. In this regard, the 
paper has explored and analysed the criteria of excellence of teachers who teach economics in the fields of continuous learning, teaching and participation in scientific research. In the existing education system of the Republic of Croatia, the quality of work of higher education teachers is measured by the criteria for selection to the scientific-teaching titles, which, on the one hand, evaluate scientific work and, on the other, particularly evaluate teaching and professional activity of teachers and their institutional contribution. In order to find out whether the mentioned criteria for teacher advancement meet the criteria of excellence of scientific research and teaching activities of higher education teachers of the countries in the region, a comparative analysis of the regulatory framework of the scientific-teaching activity of teachers in the field of social sciences - the field of economics has been conducted. Equally important is the knowledge of how much is invested in science and / or scientific research activities of teachers, since this is the only way to provide the necessary preconditions for the implementation of research projects that lead to new insights that are then transmitted and applied in business practice. Finally, it is important to emphasize that the role of higher education teachers in society is changing and, in addition to excellence in teaching and transferring expertise to future generations of professional accountants, they are increasingly expected to strongly contribute to the development and advancement of the entire community.

Keywords: education, regulatory framework, scientific-teaching activity, promotion criteria, accounting profession

JEL: M41 